\title{
A competitive analysis of EU ports by fixing spatial and economic dimensions
}

\author{
Claudio Quintano, Paolo Mazzocchi (1) and Antonella Rocca
}

\author{
* Correspondence: paolo. \\ mazzocchi@uniparthenope.it \\ Department of Management and \\ Quantitative Studies, University of \\ Naples 'Parthenope', Naples, Italy
}

\begin{abstract}
The purpose of this paper is to evaluate the efficiencies of ten of the leading European ports. The motivation of the research refers to the relevant topic of selection of indicators that can be involved in the comparative analysis. Concerning the theoretical model, the authors' efforts are especially directed towards the usage of the stochastic frontier analysis (SFA) and of the data envelopment analysis (DEA). These techniques have been widely adopted for benchmarking and performance evaluation by involving indicators based on data from National Accounts. If one of these indicators, such as labour force consistency, is not available at a specific level of aggregation, detailed assumptions are needed to address this complication. The present study proposes an additive model in order to provide an estimation of ports' economic activities by fixing the port activity boundaries and the spatial perimeter of the firms investigated. Several NUTS (Nomenclature of Territorial Units for Statistics) levels and NACE (EU Statistical Classification of Economic Activities) codes are fixed to offer a useful comparable labour indicator. Empirical results reveal that each port area presents a combination of the NACE categories which significantly impact the efficiency that can reach very high performance values through both the SFA and DEA techniques. Since the managers can choose which sectors to improve, which particular improvement strategies to support, which specific service to add, their decisions impact this performance evaluation, and their performance can be verified through the approaches proposed.
\end{abstract}

Keywords: SFA, DEA, Port, Efficiency, NUTS, NACE

\section{Introduction}

Port authorities and port operators manage the new context of supply and logistics chains. Increasing globalization has improved the strategic relevance of ports, and the attention to port efficiency has consequently grown. The traditionally strong competition among the ports affects port performance at intra-port and inter-port levels (Castelein et al. 2019). This competitiveness has encouraged management to address performance evaluation methods and benchmarking models (Figueiredo De Oliveira and Cariou 2015; European Commission 2016; Wiegmans and Witte 2017; Ferreira et al. 2018; Ha et al. 2019). The performance evaluation approaches also dedicate increasing attention to

(c) The Author(s). 2020 Open Access This article is licensed under a Creative Commons Attribution 4.0 International License, which permits use, sharing, adaptation, distribution and reproduction in any medium or format, as long as you give appropriate credit to the original author(s) and the source, provide a link to the Creative Commons licence, and indicate if changes were made. The images or other third party material in this article are included in the article's Creative Commons licence, unless indicated otherwise in a credit line to the material. If material is not included in the article's Creative Commons licence and your intended use is not permitted by statutory regulation or exceeds the permitted use, you will need to obtain permission directly from the copyright holder. To view a copy of this licence, visit http://creativecommons.org/licenses/by/4.0/. 
sustainability criteria (IAPH - International Association of Ports and Harbours 2007; Baynes et al. 2011; Chang and Wang 2012; Lam and Notteboom 2014; Laxe et al. 2016; Roos and Kliemann-Neto 2017; Chang et al. 2018).

Despite the existing remarkable literature on port performance, the subject is still quite debated. One main problem is the complexity of the port structure since various characteristics determine maritime performance, such as the number of activities linked to it, the development of intermodal transportation and undesirable outputs (OECD 2016; Madeira Jr et al. 2012; Bulut and Durur 2018; Munim and Schramm 2018; Shobayo and Van Hassel 2019). An additional issue is that there is no reliable database of collective information of international port dimensions (Cheon et al. 2010).

Concerning the selection of the measurements that can be used in the competitive analysis, several authors referred to the empirical criterion that considers the availability of inputs and outputs, while other authors suggested considering the measurements commonly adopted in previous studies (Cullinane et al. 2006). In the current work special prominence has been dedicated to the collection of data of a specific indicator, the labour consistency. In fact, the availability of labour data sources-in addition to capital and port land-represents a relevant topic in port benchmarking models (Dowd and Leschine 1990). In order to enhance this dimension, since these data are very difficult to collect, two perspectives exist in past literature. On the one hand, Tongzon (2001), Estache et al. (2002), Barros (2003), Min and Park (2005), Cullinane et al. (2006) and Turnbull (2012) proposed solutions targeted to include a proxy of the number of port' employees. On the other hand, Demirel et al. (2012) suggested the involvement of input indicators strictly connected to labour force consistency. Since both perspectives share the effort aimed at avoiding the exclusion of the labour indicator, the present paper contributes to the debate attempting to address the availability issue by means of the usage of spatial and economic patterns. The authors argue (1) that the geographical concentration of the maritime firms and (2) that an inventory of the NACE (European Statistical Classification of Economic Activities) classes related to the maritime sector can be assumed to fix homogenous and comparable indicators connected to ports. In the authors' opinion, the involvement of firms which operate in well-defined territorial districts and in specific port activities could be a good way to analyse the port performances in future research. Specifically, this paper aims to analyse the efficiency of ten of the leading European container ports focusing on the labour force estimation, and considering as a case study the port of Antwerp compared to the port of Rotterdam. The model results can be considered as implications for policymakers.

As for the theoretical model, both parametric stochastic frontier analysis (SFA) and non-parametric data envelopment analysis (DEA) were undertaken to achieve the performance investigation. Liu (1995) was among the first researchers to utilize SFA in the port sector and Barros (2005) and Cullinane et al. (2006) significantly contributed to this approach. DEA has also been widely adopted for the benchmarking and environmental performance in transportation (Roll and Hayuth 1993; Cullinane et al. 2004; Barros 2006). Among others, Ensslin et al. (2018) provided an overview of the most common port efficiency techniques. 
As for the remaining content of this article, the following section discusses the model assumptions. Section three briefly reviews the theoretical background and data. Section four combines the results and discussion. Section five refers to the case study. Section six considers the concluding remarks.

\section{Model assumptions}

In general, a performance quantitative method requires some specifications: the sample size must be appropriate, several conditions must be preserved and the results must be validated. Concerning the availability of one or more indicators, it does not represent a problem since a specific database contains the corresponding figures at a specific level of aggregation. In different conditions, the estimation of one indicator for comparative analysis requires additional assumptions. As aforementioned, in the port sector a large number of factors-such as the port features connected to the structural dimension and/or company attributes, manpower, advanced technology and port institutional reforms-need to be considered (Cheon et al. 2010; Van Den Bos and Wiegmans 2018). Nevertheless, in the current research the efficiency measurements were calculated using a limited number of variables, one input and one output in addition to the labour dimension. These indicators-discussed more in depth laterhave been obtained from the following databases: Eurostat, Bureau van Dijk, World Port Source and Harbours Review. The present paper focuses on 2016, and it was selected because it has the most comprehensive data availability.

As argued in the introduction, authors assume that the issue of the availability of the labour force consistency can be addressed considering an additive model that fixes (1) the port activity boundaries (economic activities) strictly depending on maritime activities and (2) the spatial perimeter (territorial districts) of the firms investigated.

\section{Economic activities}

Ports' behaviour of providing services to several economic sectors has been discussed in recent literature by, among others, Van Der Lugt and De Langen (2005), De Langen and Haezendonck (2012) and Alijohani and Thompson (2016). The NACE codes refer to the System of National Accounts, and the present research proposes the usage of four-digit NACE codes (classes) of port sector quoted in Table 1.

Table 1 Four-digit NACE (rev 2) classes and descriptions of the economic activities considered for each EU port

\begin{tabular}{llll}
\hline $\begin{array}{l}\text { NACE } \\
\text { code }\end{array}$ & NACE description & $\begin{array}{l}\text { NACE } \\
\text { code }\end{array}$ & NACE description \\
\hline 3011 & $\begin{array}{l}\text { Building of ships and floating } \\
\text { structures }\end{array}$ & 5030 & Inland passenger water transport \\
3012 & $\begin{array}{l}\text { Building of pleasure and sporting } \\
\text { boats }\end{array}$ & 5040 & Inland freight water transport \\
3315 & $\begin{array}{l}\text { Repair and maintenance of ships and } \\
\text { boats }\end{array}$ & 5222 & $\begin{array}{l}\text { Service activities incidental to water } \\
\text { transportation }\end{array}$ \\
5010 & $\begin{array}{l}\text { Sea and coastal passenger water } \\
\text { transport }\end{array}$ & 5224 & Cargo handling \\
5020 & Sea and coastal freight water transport & 5229 & Other transportation support activities \\
\hline
\end{tabular}

Sources: Censis (2015) 
The firms were selected by fixing 'active' companies throughout a Boolean search strategy via the Bureau van Dijk database. Nevertheless, this selection entails several weaknesses. First of all, the Bureau van Dijk database contains key establishment information, including firm name, type of activity (NACE code), number of employees and address. This classification is based on the activity declared by the establishment upon creation. Therefore, the assigned code could not exactly reflect the economic activity and/or there could be changes in the NACE classification over several years. Furthermore, the number of firms could be underestimated since some firms involved in maritime activities could have a main (primary or secondary) activity that is different from the classifications considered in the present research. Another difficulty is that some firms provide auxiliary services for maritime transportation and a distinction may be necessary. As a consequence, in addition to the NACE codes, Surís-Regueiro et al. (2013) suggested analysing the contribution of maritime activities to GDP (Gross Domestic Product) by using specific weights, which referred to economic activities that are fully or partially involved in the maritime economy. Bruno et al. (1999) proposed the entropic average as a useful indicator to investigate highly asymmetrical distributions. Interesting findings also derived from Oum and Park (2004), Fernández-Macho et al. (2016) and Heitz et al. (2018). Using a different standpoint, Baynes et al. (2011) referred to the input-output (I/O) approach as proposed by Leontief (1936).

\section{Territorial districts}

If one assumes that a firm's location near a port increases its probability of depending upon the port to exist, then comparison of the spatial dimension appears to be a sustainable perspective. The approach prioritizes the proximity as a key element in defining an appropriate cluster of activities and it has been analysed by, among others, Rivera et al. (2014). These authors defined the clusters in logistics and transportation by considering the geographic concentration of firms providing logistics services. NUTS2 (Nomenclature of Territorial Units for Statistics) classifications represent territorial districts allowing for harmonized and comparable socio-economic analyses. Therefore, the usage of the NUTS2 level appears to be suitable to ensure a high degree of homogeneity of the geographical division. Eurostat $(2009,2017)$ referred to the NUTS2 codes to analyse different maritime policies and several tourism flows across the EU. According to this perspective, in the

Table 2 NUTS2 levels considered for the ports analysed in the present research, and number of firms involved

\begin{tabular}{lll}
\hline Port & NUTS2 level & Number of firms \\
\hline Algeciras & ES61 - Andalucia & 788 \\
Amsterdam & NL32 - Noord-Holland & 2130 \\
Antwerp & BE21 - Antwerp & 718 \\
Bremerhaven & DE50 - Bremen & 609 \\
Hamburg & DE60 - Hamburg & 2111 \\
Le Havre & FR23 - Haute-Normandie & 122 \\
Marseille & FR82 - Provence-Alpes-Cote D'Azur & 321 \\
Rotterdam & NL33 - Zuid-Holland & 3900 \\
Trieste & ITH4 - Friuli-Venezia Giulia & 440 \\
Valencia & ES52 - Comunidad Valenciana & 710 \\
\hline
\end{tabular}


current paper labour force consistency has been estimated by fixing the firms located in the NUTS2 regions mentioned in Table 2, and those involved in the NACE codes quoted in the above-mentioned Table 1. Data from a sample of 11,849 active firms has been considered. Table 2 also shows the number of firms involved in each NUTS2 level.

\section{Theoretical background and data Methodology}

The literature differentiates between two fundamental methodologies for measuring efficiency through the functional form: the non-parametric linear programming technique-DEA - and the parametric model-SFA. As discussed in the introduction, both the SFA and DEA approaches have been commonly considered in the port performance literature. Barros et al. (2011, b), Odeck and Bråthen (2012) and Lampe and Hilgers (2015) presented an extensive description, assumptions and differences between the SFA and DEA perspectives.

Selected studies connected to the usage of DEA and SFA in previous port literature can be found in Table 3. This table also summarises the approaches proposed by each research paper and the indicators used in each work.

\section{Data}

In this paper the variables were selected after reviewing the existing literature quoted in Table 3; the first input dimension is the number of employees (Roll and Hayuth 1993; Coto-Millan et al. 2000; Notteboom et al. 2000; Estache et al. 2002; Barros 2003, 2006, 2012; Min and Park 2005; Rios and Maçada 2006; Barros and Peypoch 2007; Panayides et al. 2011; Gong et al. 2019). De Langen and Pallis (2006), Turnbull and Wass (2007) and Murphy et al. (2016) highlighted that, even though the capitalintensive paradigm is increasing in the port sector, the labour remains an important dimension in port competition. The economic efficiency of the labour market significantly influences the productivity, thus inefficient work procedures can cause inefficiencies in port operations. Notteboom $(2010,2012)$ emphasized that several features impact the port labour cost and competitiveness, for instance direct and indirect (or hidden) costs (such as strikes, absenteeism, inactivity for accidents/sickness), technological innovations, introduction of new cargo handling equipment, etc. Port labour environment also changes as a consequence of port reform, new port security regulation, labour port schemes, etc.

In the present work authors assume that the managers' efforts are addressed to maximize the goods handled in each port involved in the analysis (the correlation matrix of the input and output variables presents a positive relationship among the indicators). This perspective represents one of two different schools of thought on labour assumptions. In fact, on the one hand, if one assumes this positive correlation, port policy measures can be targeted to increase the port throughput to expand the labour component (Ferrari et al. 2010; Bottasso et al. 2013). On the other hand, different authors, such as Grobar (2008) and Deng et al. (2013), noted that recent advancements in transportation technology have modified the role of ports in local economic development. For instance, in the container sector, the transportation activity has made the process of goods movement much more capital intensive, thus decreasing the local 
Table 3 Input and output variables used in previous port studies

\begin{tabular}{|c|c|c|c|c|}
\hline Reference & Research object & Model & Outputs & Inputs \\
\hline $\begin{array}{l}\text { Almawsheki } \\
\text { and Shah } \\
\text { (2015) }\end{array}$ & $\begin{array}{l}\text { Technical efficiency of } \\
\text { container terminals }\end{array}$ & DEA & Throughput (TEU) & $\begin{array}{l}\text { Terminal area } \\
\text { Quay length } \\
\text { Quay crane } \\
\text { Yard equipment } \\
\text { Maximum draft }\end{array}$ \\
\hline Barros (2003) & Efficiency of container ports & DEA & $\begin{array}{l}\text { Ships } \\
\text { Movement of freight } \\
\text { Gross gauge } \\
\text { Break bulk cargo } \\
\text { Containerized freight } \\
\text { Solid bulk and liquid bulk }\end{array}$ & $\begin{array}{l}\text { Total length of } \\
\text { berth } \\
\text { Container berth } \\
\text { length } \\
\text { Number of } \\
\text { employees } \\
\text { Capital (Book } \\
\text { value of asset) }\end{array}$ \\
\hline Barros (2006) & Efficiency of container ports & DEA & $\begin{array}{l}\text { Liquid bulk } \\
\text { Dry bulk } \\
\text { Number of ships } \\
\text { Number of passenger } \\
\text { Number of containers } \\
\text { Total sales }\end{array}$ & $\begin{array}{l}\text { Number of } \\
\text { employees } \\
\text { Value of capital } \\
\text { invested } \\
\text { Size of operating } \\
\text { Costs }\end{array}$ \\
\hline Barros (2012) & Seaport performance & DEA & $\begin{array}{l}\text { TEU } \\
\text { Dry bulk } \\
\text { Liquid bulk } \\
\text { Delays in handling ship } \\
\text { cargo }\end{array}$ & $\begin{array}{l}\text { Quay length } \\
\text { Seaport area } \\
\text { Labour }\end{array}$ \\
\hline $\begin{array}{l}\text { Barros and } \\
\text { Peypoch } \\
\text { (2007) }\end{array}$ & Seaport productivity & $\begin{array}{l}\text { Distance Function, } \\
\text { Luenberger } \\
\text { Indicator }\end{array}$ & $\begin{array}{l}\text { Total containers } \\
\text { Sales } \\
\text { Liquid bulk } \\
\text { Solid bulk } \\
\text { Ships }\end{array}$ & $\begin{array}{l}\text { Total operational } \\
\text { cost } \\
\text { Number of } \\
\text { employees } \\
\text { Investment }\end{array}$ \\
\hline $\begin{array}{l}\text { Barros et al. } \\
\text { (2011) }\end{array}$ & Efficiency of container ports & $\begin{array}{l}\text { Luenberger } \\
\text { Indicator, } \\
\text { Malmquist Index }\end{array}$ & $\begin{array}{l}\text { Throughout } \\
\text { Number of ship calls }\end{array}$ & $\begin{array}{l}\text { Number of } \\
\text { employees } \\
\text { Total cost } \\
\text { Number of cranes }\end{array}$ \\
\hline $\begin{array}{l}\text { Coto-Millan } \\
\text { et al. (2000) }\end{array}$ & Seaport efficiency & SFA & $\begin{array}{l}\text { Total of goods moved in } \\
\text { the port } \\
\text { Passengers embarked and } \\
\text { disembarked } \\
\text { Number of vehicle with } \\
\text { passengers }\end{array}$ & $\begin{array}{l}\text { Labour } \\
\text { Capital } \\
\text { Intermediate } \\
\text { consumptions }\end{array}$ \\
\hline $\begin{array}{l}\text { Cullinane } \\
\text { et al. (2006) }\end{array}$ & Efficiency of container ports & SFA & $\begin{array}{l}\text { Container throughput } \\
\text { (TEU) }\end{array}$ & $\begin{array}{l}\text { Terminal length } \\
\text { Terminal area } \\
\text { Number of } \\
\text { quayside gantry } \\
\text { cranes } \\
\text { Number of yard } \\
\text { gantry cranes } \\
\text { Number of } \\
\text { straddle carriers }\end{array}$ \\
\hline $\begin{array}{l}\text { Demirel et al. } \\
\text { (2012) }\end{array}$ & Efficiency of container ports & DEA & Container Throughput (TEU) & $\begin{array}{l}\text { Quay length } \\
\text { Terminal area } \\
\text { Quay cranes } \\
\text { Yard equipment } \\
\text { Maximum draft }\end{array}$ \\
\hline $\begin{array}{l}\text { Estache et al. } \\
\text { (2002) }\end{array}$ & $\begin{array}{l}\text { Efficiency gains from port } \\
\text { reform in Mexico }\end{array}$ & SFA & Handling volume (tons) & $\begin{array}{l}\text { Number or } \\
\text { workers } \\
\text { Lengh of docks }\end{array}$ \\
\hline $\begin{array}{l}\text { Gong et al. } \\
\text { (2019) }\end{array}$ & $\begin{array}{l}\text { Shipping companies ( } 73 \% \\
\text { involved in the container } \\
\text { sector) }\end{array}$ & DEA & $\begin{array}{l}\text { Cargo carried } \\
\text { Revenue } \\
\text { Undesirable outputs }\end{array}$ & $\begin{array}{l}\text { Total assets } \\
\text { Capital } \\
\text { expenditure } \\
\text { Capacity } \\
\text { Number of ships } \\
\text { Employees } \\
\text { Fuel cost }\end{array}$ \\
\hline $\begin{array}{l}\text { Min and Park } \\
\text { (2005) }\end{array}$ & Efficiency of container ports & DEA & Cargo throughput & $\begin{array}{l}\text { Size of labour } \\
\text { force } \\
\text { Total length of }\end{array}$ \\
\hline
\end{tabular}


Table $\mathbf{3}$ Input and output variables used in previous port studies (Continued)

\begin{tabular}{|c|c|c|c|c|}
\hline Reference & Research object & Model & Outputs & Inputs \\
\hline & & & & $\begin{array}{l}\text { query } \\
\text { Number of cranes } \\
\text { Size of hard areas }\end{array}$ \\
\hline $\begin{array}{l}\text { Nguyen et al. } \\
\text { (2016) }\end{array}$ & $\begin{array}{l}\text { Efficiency of Vietnamese } \\
\text { ports }\end{array}$ & $\begin{array}{l}\text { Bootstrap DEA \& } \\
\text { SFA }\end{array}$ & Throughput & $\begin{array}{l}\text { Berth length } \\
\text { Terminal areas } \\
\text { Warehouse } \\
\text { capacity } \\
\text { Cargo handling } \\
\text { equipment }\end{array}$ \\
\hline $\begin{array}{l}\text { Notteboom } \\
\text { et al. (2000) }\end{array}$ & Efficiency of container ports & SFA & Container traffic & $\begin{array}{l}\text { Terminal quay } \\
\text { length } \\
\text { Terminal area } \\
\text { Number of gantry } \\
\text { cranes } \\
\text { Average no. of } \\
\text { workers per crane }\end{array}$ \\
\hline $\begin{array}{l}\text { Panayides } \\
\text { et al. (2011) }\end{array}$ & $\begin{array}{l}\text { Efficiency of shipping } \\
\text { companies }\end{array}$ & DEA and SFA & $\begin{array}{l}\text { Market value of equity } \\
\text { Sales }\end{array}$ & $\begin{array}{l}\text { Inputs profits } \\
\text { Book value of } \\
\text { equity } \\
\text { Total assets } \\
\text { Number of } \\
\text { employees } \\
\text { Capital } \\
\text { expenditure }\end{array}$ \\
\hline $\begin{array}{l}\text { Rios and } \\
\text { Maçada } \\
\text { (2006) }\end{array}$ & Efficiency of container ports & DEA & $\begin{array}{l}\text { TEUs handled } \\
\text { Average number of } \\
\text { containers handled per hour } \\
\text { per ship }\end{array}$ & $\begin{array}{l}\text { Number of cranes } \\
\text { Number of berths } \\
\text { Number of } \\
\text { employees } \\
\text { Terminal area } \\
\text { Amount of yard } \\
\text { equipment }\end{array}$ \\
\hline $\begin{array}{l}\text { Roll and } \\
\text { Hayuth (1993) }\end{array}$ & Port performance & DEA & $\begin{array}{l}\text { Container throughput } \\
\text { Service level } \\
\text { User satisfaction } \\
\text { Ship calls }\end{array}$ & $\begin{array}{l}\text { Size of labour } \\
\text { force } \\
\text { Annual } \\
\text { investment per } \\
\text { port } \\
\text { The uniformity of } \\
\text { facilities and } \\
\text { cargo }\end{array}$ \\
\hline $\begin{array}{l}\text { Suárez- } \\
\text { Alemán et al. } \\
\text { (2016) }\end{array}$ & Container port efficiency & SFA & TEU throughput & $\begin{array}{l}\text { Terminal area, } \\
\text { No. of mobile } \\
\text { cranes } \\
\text { No. of gantry } \\
\text { cranes } \\
\text { Berth length } \\
\text { Exogenous } \\
\text { variables }\end{array}$ \\
\hline $\begin{array}{l}\text { Tongzon } \\
\text { (2001) }\end{array}$ & Efficiency of container ports & DEA & $\begin{array}{l}\text { Cargo throughput (TEU) } \\
\text { Ship working rate }\end{array}$ & $\begin{array}{l}\text { Number of berths } \\
\text { Number of cranes } \\
\text { Number of tugs } \\
\text { Number of port } \\
\text { authority } \\
\text { Employees } \\
\text { Delay time }\end{array}$ \\
\hline
\end{tabular}

employment benefits of having a port. If this standpoint prevails, the implications on the port throughput are less clear.

The second input measurement refers to the terminal quay length of each port. This dimension has strategic importance in terms of time waiting as a performance indicator (Notteboom et al. 2000; Cullinane et al. 2006; Rios and Maçada 2006; Almawsheki and Shah 2015; Barros 2003, 2012; Panayides et al. 2011; Demirel et al. 2012; Nguyen et al. 2016; Suárez-Alemán et al. 2016). This dimension appears to be as a more neutral measurement than the container quay length, since ports can have a different division 
between diverse output products in their trade (for instance, Rotterdam is traditionally focused on bulk).

In regard to the output, current research considers the total gross weight of goods handled in each port (bulk and containers) which is expressed in thousands of tons. According to Table 3, also this dimension represents a widely accepted indicator of port output. Eurostat (2020) highlighted that Rotterdam was the largest European port for all types of cargo in 2019, with almost 110 million tons for each quarter. The second port in the same year was Antwerp which handled close to half of the tonnage recorded by Rotterdam, while the third port was Hamburg. Considering only the container cargo segment, the ranking is similar and Rotterdam, Antwerp and Hamburg remained the three main European ports in 2019, followed by the two Spanish ports of Algeciras and Valencia. In contrast, slight differences in ranking appear observing diverse types of bulk.

Table 4 provides the descriptive statistics of the input and output measurements included in the model.

$D E A$

DEA represents a widely utilised method to obtain a multi-variate frontier estimation and to measure the efficiency of multiple homogeneous DMUs (decisions making units) with the same set of inputs and outputs. The original idea behind the DEA model can be traced back to Farrell (1957), while the model was significantly advanced by Charnes et al. (1978) and Banker et al. (1984). This technique does not require a specific functional relationship among inputs and outputs. Both the input and output orientations can be used, and several technologies are available: constant returns to scale (CRS, or CCR), variable returns to scale (VRS, or BCC), and non-increasing returns to scale (NIRS). Following the definition proposed by Cook and Zhu (2005), eq. (1) summarizes the two-stage input DEA approach.

$$
\begin{aligned}
& \min \theta_{0}-\varepsilon\left(\sum_{i=1}^{m} s_{i}^{-}+\sum_{r=1}^{s} s_{r}^{+}\right) \\
& \text {subject to } \\
& \sum_{j=1}^{n} \lambda_{j} x_{i j}+s_{i}^{-}=\theta_{0} x_{i 0} \quad(i=1, \ldots, m) \\
& \sum_{j=1}^{n} \lambda_{j} y_{j h}-s_{r}^{+}=y_{r 0} \quad(r=1, \ldots, s) \\
& \lambda_{j}, s_{r}^{+}, s_{i}^{-} \geq 0
\end{aligned}
$$

\begin{tabular}{|c|c|c|c|c|c|c|c|}
\hline Description & Minimum & Maximum & $\begin{array}{l}\text { 1st } \\
\text { q. }\end{array}$ & Median & Mean & $\begin{array}{l}\text { 3st } \\
\text { q. }\end{array}$ & $\begin{array}{l}\text { Standard } \\
\text { deviation }\end{array}$ \\
\hline $\begin{array}{l}\text { Total gross weight of goods handled in } \\
\text { each port }{ }^{\mathrm{a}}[\mathrm{TGW} \text { (thousands of tons) }\end{array}$ & 49,137 & 436,942 & $\begin{array}{l}58 \\
905\end{array}$ & 78,427 & $\begin{array}{l}122 \\
224\end{array}$ & $\begin{array}{l}114 \\
823\end{array}$ & 112,400 \\
\hline $\begin{array}{l}\text { Number of employees }{ }^{b} \\
\text { [NOE] }\end{array}$ & 4785 & 98,679 & $\begin{array}{l}13, \\
956\end{array}$ & 23,418 & $\begin{array}{l}33 \\
101\end{array}$ & $\begin{array}{l}48 \\
126\end{array}$ & 27,001 \\
\hline $\begin{array}{l}\text { Terminal quay length }{ }^{c} \\
{[C T L]}\end{array}$ & 1700 & 157,000 & $\begin{array}{l}12 \\
000\end{array}$ & 25,450 & $\begin{array}{l}43 \\
310\end{array}$ & $\begin{array}{l}65 \\
625\end{array}$ & 44,965 \\
\hline
\end{tabular}

Table 4 Descriptive statistics of the indicators involved in the DEA and SFA approaches

Sources: ${ }^{\mathrm{a} E u r o s t a t}$ database; ${ }^{\mathrm{b}}$ Bureau van Dijk; ${ }^{\mathrm{C} W o r l d ~ P o r t ~ S o u r c e ~(w w w . w o r l d p o r t s o u r c e . c o m ; ~ B r e m e r h a v e n, ~ L e ~ H a v r e, ~}$ Marseille, Valencia), Harbours Review (http://harboursreview.com; Algeciras, Amsterdam, Antwerp, Hamburg, Rotterdam) and www.porto.trieste.it (Trieste) 
In this equation $\theta$ denotes the efficiency score for each DMU; $s_{i}^{-}$and $s_{r}^{+}$represent input and output slacks; the non-Archimedean $\varepsilon$ allows the minimization involving the slacks; $x_{i}$ is the $i$-th input of $m$ inputs; $y_{r}$ indicates the $r$-th output of $s$ outputs; $\lambda_{j}$ is a non-negative scalar. In addition to the radial approach, the non-radial efficiency measurements have also been considered in the DEA models. Zhou et al. (2007) highlighted that the non-radial DEA seems to be more effective in measuring the environmental performance, since this approach has a high discriminating power in evaluating the DMU's efficiencies. Cook and Seiford (2009) presented a detailed review of the DEA techniques, while Sahoo et al. (2016) and Liu et al. (2016) proposed innovative DEA approaches.

\section{SFA}

The SFA approach was developed by Aigner et al. (1977) and Meeusen and Van den Broeck (1977). Battese and Coelli $(1992,1995)$ significantly expanded the basic model. In contrast to DEA, SFA requires the specification of a parametric function. The most popular parametrization of the model refers to the Cobb-Douglas (log) function, which can be exhibited in form of multiplicative specifications as shown in eq. (2).

$$
y=f(x ; \beta) \exp (v-u)
$$

In this equation, $y$ is a scalar output, while $x$ is a vector of the inputs. $\beta$ is a vector of the technology parameters. The composed error refers to the decomposition of the error term $\varepsilon$ into the two components represented by $\varepsilon=v-u . v \sim N\left(0, \sigma_{v}^{2}\right)$ is the first error component, that concerns the effects of the statistical noise, and it is unrestricted in sign. $u$ is the second error component, and it considers the effects of technical inefficiency $(u \geq 0) . u$ is considered to have a distribution such as the exponential or half normal $u \sim N_{+}\left(0, \sigma_{u}^{2}\right)$, to ensure that it produces only non-negative values. The model assumes that the corresponding log-likelihood function needs to be maximized, by using the maximum likelihood method (Kumbhakar and Lovell 2003). The stochastic version of output-oriented technical efficiency proposed by Coelli et al. (2005) is shown in eq. (3):

$$
T E=\frac{y}{f(x) e^{v}}=\frac{f(x) e^{-u} e^{v}}{f(x) e^{v}}=\exp (-u)
$$

where TE indicates the technical efficiency of production obtained as a ratio between the observed output $(y)$ and the corresponding stochastic frontier output; $e^{-u}$ denotes the inefficiency; $e^{v}$ represents the noise. Different functional forms can be used, instead of using the traditional Cobb-Douglas (log) function. In this article the performance evaluation derived from the translog SFA as proposed by Christensen et al. (1973). Translog SFA represents a less restrictive approach compared to the standard CobbDouglas function.

In the prevalent literature, the SFA technique is less frequently used than the DEA. One main reason is that multiple input and output measurements limit the usage of the SFA technique in the standard version. In fact, when the SFA model needs to consider multiple outputs instead of a single one, the standard econometric approach requires that input and output prices are available. An extensive consideration of DEA 
and SFA techniques is beyond the scope of this paper while the actual purpose of this paper is to include the radial DEA and SFA techniques to (1) verify if the model provides consistent results and (2) evaluate a specific labour port perspective. See Orea and Wall (2016) for a comprehensive discussion on these topics.

\section{Results and discussion}

Table 5 shows the efficiency scores of the ten European ports, according to the following techniques: the VRS output orientation (DEA_VRS_OUT); the VRS input orientation (DEA_VRS_IN); the CRS (DEA_CRS); and translog SFA (SFA_TR_LG).

Spearman correlations have been calculated by considering the DEA and SFA efficiency scores to verify whether the ports' ranks are (approximately) the same. The results are provided in Table 6. As can be seen in the table, all the ranking correlations among the diverse techniques are positive, and the Spearman correlation between $S F A_{-}$ $T R \_L G$ and DEA_CRS appears to be relatively high. According to the results of the statistical analysis, even though the efficiency scores slightly differ among the different techniques, the efficiency scores do not present conflicting results.

Figures 1a-b-c show the (positive) relationship between $S F A \_T R \_L G$ and the DEA efficiency estimates.

Table 5 indicates that in the DEA-VRS approach three ports (Le Havre, Marseille and Rotterdam) are on the efficient frontier using both the input and output orientations. This result is consistent with the distinction between the input and output DEA orientations which reflect the different ways of reaching the efficient production frontier. Two ports, Le Havre and Marseille, also show the best score in the DEA-CRS approach, while Rotterdam decreases its performance marginally. Rotterdam and Amsterdam present the best score in the translog SFA technique. Several other ports operate at a high level of efficiency, for instance Antwerp and Algeciras. Bremerhaven appears to be inefficient in both SFA and DEA approaches. Compared to the other ports, Marseille has very low values of the terminal quay length, while Le Havre presents the minimum value of number of employees and Rotterdam has the maximum value of total gross weight of goods handled. In the DEA approach, since the efficient ports determine the technology set, the consequences are (1) that at least one port has its efficiency equal to 1 and (2) the number of inputs and outputs used in the model determines the number of efficient ports. In contrast, in the SFA approach, ports have efficiency equal to 1

Table 5 DEA and SFA efficiency scores for each port

\begin{tabular}{lllll}
\hline Port & DEA_VRS_OUT & DEA_VRS_IN & DEA_CRS & SFA_TR_LG \\
\hline Algeciras & 0.64 & 0.56 & 0.51 & 0.93 \\
Amsterdam & 0.52 & 0.44 & 0.35 & 0.94 \\
Antwerp & 0.71 & 0.68 & 0.46 & 0.84 \\
Bremerhaven & 0.20 & 0.16 & 0.11 & 0.78 \\
Hamburg & 0.36 & 0.19 & 0.16 & 0.92 \\
Le Havre & 1 & 1 & 1 & 0.89 \\
Marseille & 1 & 1 & 1 & 0.91 \\
Rotterdam & 1 & 1 & 0.69 & 0.94 \\
Trieste & 0.37 & 0.38 & 0.27 & 0.91 \\
Valencia & 0.55 & 0.53 & 0.46 & 0.85 \\
\hline
\end{tabular}


Table 6 Spearman rank correlations among the efficiency scores obtained by different techniques

\begin{tabular}{llll}
\hline & DEA_VRS_OUT & DEA_VRS_IN & DEA_CRS \\
\hline DEA_VRS_OUT & 1 & & \\
DEA_VRS_IN & 1 & 1 & 1 \\
DEA_CRS & $0.969^{\mathrm{a}}$ & $0.969^{\mathrm{a}}$ & $0.569^{*}$ \\
SFA_TR_LG & 0.185 & 0.185 &
\end{tabular}

Notes: * Spearman correlation is significant at the 0.05 level (2-tailed); ${ }^{\text {a }}$ Spearman correlation is significant at the 0.01 level (2-tailed)

only when $u=0$. Therefore, there are firms with a DEA efficiency equal to 1 but have much lower SFA efficiency scores. The port policy actions aimed at inefficient ports should be considered by referring to these efficient ports to improve operational performance. Specifically, these policies could refer to the efficient 'peer' ports, since the DEA 'principle of dominance' assumes that an inefficient DMU is dominated by one (or more) peer(s) that presents the best practices.

Diverse relevant features are missing in the present analysis: the peer weights (or benchmarks), the mathematical derivation of the slacks for the efficient ports (in radial model), hypothesis tests of the different CRS/VRS technologies, and extensive explorations of the causes of the variation in the efficiency (and of the validation of the approaches proposed). Similarly, in the SFA approach, several control variables could be considered because they can have an impact on the estimated efficiency values. In fact, in addition to the estimation of the efficiency, the SFA analyses factors determining the variations in the level of efficiency. These features are beyond the aim of this paper. Concerning the indicators' assumptions needed to perform the competitive SFA and DEA, since the models can both be consistently wrong and both could report the same erroneous results, the fact that DEA and SFA appear to provide consistent results does not validate the assumptions of the model. As a consequence, the selection of the dimensions, the choice over the NACE codes, the signs of the values and the results of past studies require an appropriate corresponding analysis and further investigation.

In regard to the SFA's maximum-likelihood estimates, Table 7 indicates the corresponding results.

These maximum likelihood values can be also reported in equation form to estimate the translog production frontier, as follows in eq. (4).

$$
\begin{aligned}
\ln (T G W)= & 80.75 \\
& +3.09 \ln (N O E)-17.46 \ln (C T L)-1.22 \ln \left(N O E^{2}\right)-0.19 \ln \left(C T L^{2}\right) \\
& +2.16 \ln (N O E) \ln (C T L)+(v-u)
\end{aligned}
$$

The results indicate the $\beta$ coefficients have different sign and size between standard and translog SFA. The number of employees is positively affecting output and it is statistically significant. This positive correlation with the port's output results consistent with the authors assumption. Nevertheless, the sign of 'square of number of employees' is negative, which indicates that the output increases but in decreasing manner. The negative and statistically significant coefficient of 'terminal quay length' suggests that the higher the terminal quay length, the smaller the output. This finding is coherent with the involvement of a dimension (the terminal quay length) that is a more neutral measurement compared to the container quay length since each port activity is no 


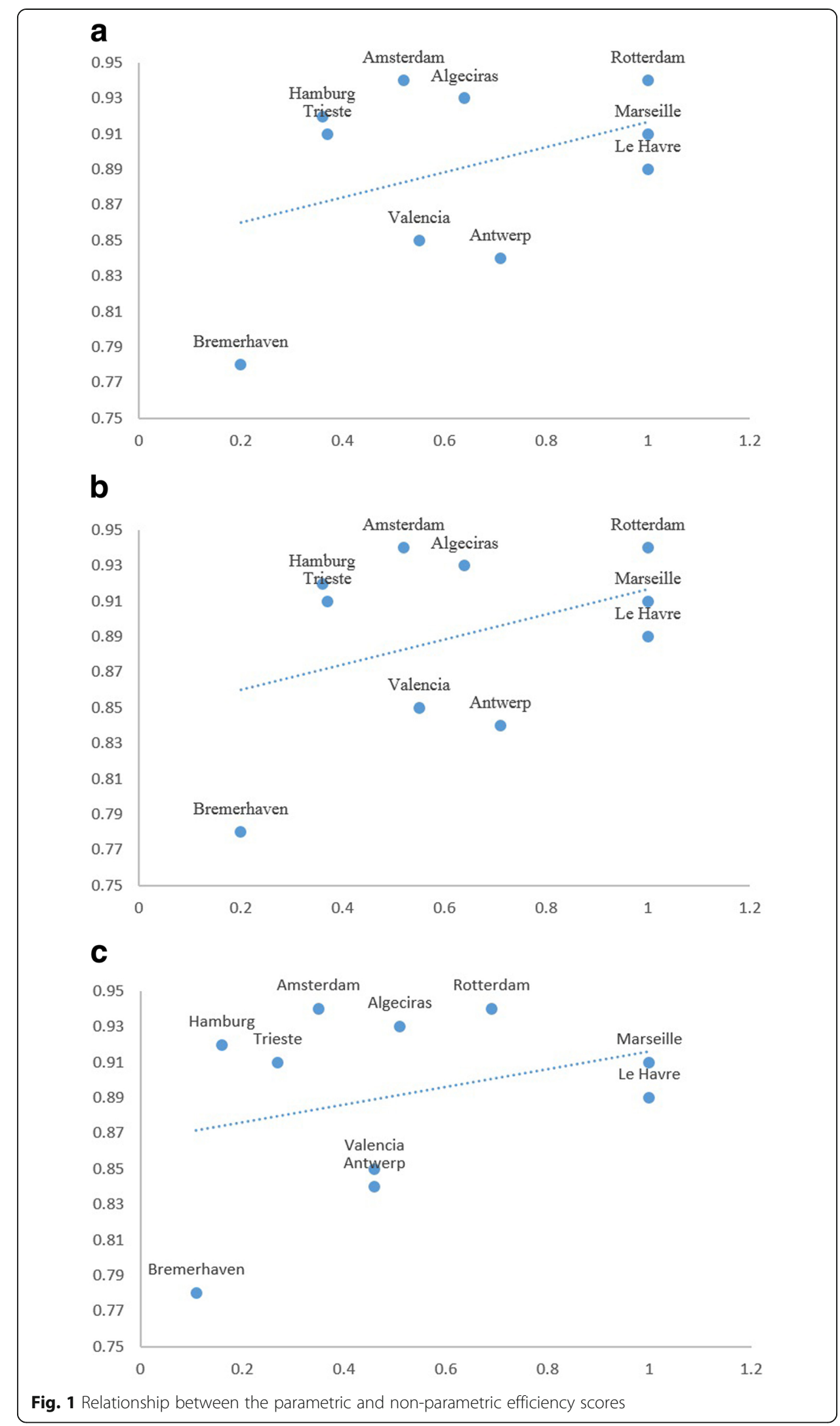


Table 7 Standard and translog SFA estimates

\begin{tabular}{|c|c|c|}
\hline Variables & Translog SFA coefficient & $\beta$ coefficients \\
\hline Constant & $80.75^{\mathrm{a}}$ & $\beta_{0}$ \\
\hline Number of employees & $3,09^{b}$ & $\beta_{1}$ \\
\hline Terminal quay length & $-17.46^{\mathrm{a}}$ & $\beta_{2}$ \\
\hline Number of employees ${ }^{2}$ & -1.22 & $\beta_{3}$ \\
\hline Terminal quay length ${ }^{2}$ & -0.19 & $\beta_{4}$ \\
\hline Number of employees \& Terminal quay length & 2.16 & $\beta_{5}$ \\
\hline$\sigma^{2}$ & 0.07 & \\
\hline$\sigma_{v}^{2}$ & 0.033 & \\
\hline$\sigma_{u}^{2}$ & 0.033 & \\
\hline
\end{tabular}

longer limited to just the containers' handling. Concerning the parameters of the technical efficiency model, the signs of the determinants need to be analysed as well to verify if they result in an increase or in a decrease of the inefficiency of the ports.

\section{Case study}

The conceptual framework presented in this paper is empirically analysed considering the port of Antwerp in the different scenarios. The port of Antwerp represents the most extensive port area in the world and several recent research contributions focused on this port in empirical analysis (Haezendonck and Langenus 2019; Leloup 2019). Among others, Esser et al. (2019) discussed the importance of this port as a job generator for the province of Antwerp. This port experienced exceptional economic growth in the last decade, and it has been selected as a case study because DEA and SFA techniques offer significantly different performance estimations among the diverse scenarios.

It is important to underline that the set of ten ports analysed in the paper presents heterogeneous features which should be taken into account, even though this investigation is not discussed in the present paper. For instance, Table 8 provides the (significantly different) distribution of firms by NACE codes and container ports, while Table 9 shows the distribution of firms by NACE codes and firm sizes.

Furthermore, present work does not consider additional features connected-for instance-to the diverse company's financial characteristics, the standardized legal form, the full-time (or part-time) prevalent jobs structure, etc. In addition to Antwerp, the present case study considers the port of Rotterdam to compare the results. The remaining eight ports are excluded from the analysis even though each of them presents specific relevant characteristics. One might think to the port of Marseille that experienced (1) a recent port reform (Lacoste and Douet 2013) and (2) increasing investments to realize an efficient integration of this port with the hinterland (Cariou et al. 2014). Therefore, further research is required on different ports and contextual factors that could potentially affect the results.

Assuming that management and port authorities are able to influence port performance, the economic significance of the current model refers to the specific policies that can be used to stimulate ports' behaviour towards diverse topics. Current case study 
Table 8 Distribution of firms by NACE codes and ports

\begin{tabular}{llllllllllll}
\hline $\begin{array}{l}\text { NACE code } \\
\text { Port }\end{array}$ & $\mathbf{3 0 1 1}$ & $\mathbf{3 0 1 2}$ & $\mathbf{3 3 1 5}$ & $\mathbf{5 0 1 0}$ & $\mathbf{5 0 2 0}$ & $\mathbf{5 0 3 0}$ & $\mathbf{5 0 4 0}$ & $\mathbf{5 2 2 2}$ & $\mathbf{5 2 2 4}$ & $\mathbf{5 2 2 9}$ & Total \\
\hline Algeciras & 37 & 9 & 143 & 20 & 30 & 24 & 2 & 135 & 45 & 343 & 788 \\
Amsterdam & 57 & 178 & 224 & 47 & 57 & 380 & 148 & 322 & 157 & 560 & 2130 \\
Antwerp & 6 & & 30 & 2 & 40 & 1 & 135 & 31 & 129 & 344 & 718 \\
Bremerhaven & 26 & 11 & 6 & 7 & 89 & 4 & 14 & 70 & 20 & 362 & 609 \\
Hamburg & 30 & 13 & 11 & 44 & 465 & 15 & 55 & 246 & 41 & 1191 & 2111 \\
Le Havre & 1 & 1 & 7 & 2 & 4 & & 17 & 9 & 18 & 63 & 122 \\
Marseille & 5 & 13 & 115 & 18 & 10 & 1 & & 26 & 17 & 116 & 321 \\
Rotterdam & 96 & 114 & 269 & 41 & 136 & 120 & 1124 & 683 & 213 & 1104 & 3900 \\
Trieste & 53 & 47 & 107 & 3 & 2 & & & 40 & 48 & 140 & 440 \\
Valencia & 17 & 11 & 72 & 15 & 14 & 7 & 2 & 110 & 25 & 437 & 710 \\
\hline
\end{tabular}

suggests the involvement of different combinations of NACE codes for each scenario, that result in significantly different clusters of firms (and employees) analysed. Ten different scenarios have been proposed considering DEA_CRS and SFA_TR_LG scores, since these approaches presented the highest Spearman correlation. The first scenario refers to the whole set of NACE codes quoted in Table 1. Differently, the second scenario includes only the 3011 code, while the third scenario adds to this code the number of workers belonging to 3012 code, and so on. Table 10 shows the step-by-step procedure and the different efficiency scores, while Fig. 2 visually indicates the relationship among these scores for each scenario.

Empirical results reveal that the port of Antwerp presents different efficiency values for each scenario, and it reaches very high performance values through both the SFA and DEA techniques. This finding confirms that the combination of the NACE categories significantly impacts the performance evaluation. Managers can choose which sectors to improve, which particular improvement strategies to support, which specific service to add, and so on. One example could refer to the services for passengers and/ or the concessions of the ferry routes even though they often require political decisions (Wergeland 2016), and/or the measures to support operational costs caused by

Table 9 Port of Antwerp: Distribution of firms by NACE codes and firm size

\begin{tabular}{lllll}
\hline $\begin{array}{l}\text { Firm size } \\
\text { NACE code }\end{array}$ & Large & Medium & Small & Micro \\
\hline 3011 & & 3 & 1 & 5 \\
3315 & & & 9 & 18 \\
5010 & 1 & 1 & 8 & 30 \\
5020 & & & & 1 \\
5030 & 2 & 1 & 2 & 132 \\
5040 & 8 & 3 & 6 & 20 \\
5222 & 4 & 24 & 46 & 61 \\
5224 & 4 & 24 & 104 & 212 \\
5229 & 4229 & 104 & 212 \\
\hline
\end{tabular}

Note: The European Commission recommendation 2003/361 defines the 'standards for small and medium-sized enterprises' as follows: large $>250$ employees; medium $<250$ employees; small $<50$ employees; micro $<10$ 
accidents and dangerous port occurrences (Antão et al. 2016). In general, it is very important to mitigate the potential inaccuracies of involving specific labour categories in the port handling sector. Nevertheless, several NACE codes involved in the analysis could be inadequate. For instance, categories such as ship repairs (NACE codes 3011, 3012, 3315) and passenger-related services (NACE codes 5010 and 5030) have limited relevance with container terminals. In the authors' opinion, the usage of a broader selection of the port activities appears to be appropriate in the present analysis, although additional proxies and/or different NACE selection can be considered in further investigation.

\section{Conclusion}

The indicators' assumptions proposed to perform the performance analysis represent the major concern for the benchmarking study. This article investigates the performances of ten European ports and it assumes that the widely debated labour indicator can be estimated by fixing the firms involved in the NACE codes and NUTS2 regions. Empirical results show that, on the one hand, this approach could be useful in avoiding the exclusion of this measurement due to difficulties in collecting labour data. On the other hand, since the NACE selection impacts on the benchmarking, it is important to address the issue connected to the usage of the labour force via a coherent and consistent model. Supplementary finding derives from the results of both SFA and DEA techniques that do not present conflicting results. The Spearman coefficients show positive ranking correlations (which is relatively high considering translog SFA and DEA CRS). The outcomes of the empirical study confirm that policy actions can refer to these

Table 10 DEA and SFA efficiency scores: (CRS) DEA and SFA results

\begin{tabular}{|c|c|c|c|c|c|c|c|c|c|c|c|c|c|}
\hline & & 3011 & 3012 & 3315 & 5010 & 5020 & 5030 & 5040 & 522 & 5224 & 5229 & DEA_CRS & SFA_TR_LG \\
\hline \multirow[t]{2}{*}{1} & Antwerp & $\cdot$ & . & . & . & . & . & . & . & . & . & 0.46 & 0.84 \\
\hline & Rotterdam & & & & & & & & & & & 0.69 & 0.94 \\
\hline \multirow[t]{2}{*}{2} & Antwerp & $\cdot$ & & & & & & & & & & 0.60 & 0.85 \\
\hline & Rotterdam & & & & & & & & & & & 0.35 & 0.81 \\
\hline \multirow[t]{2}{*}{3} & Antwerp & · & - & & & & & & & & & 0.69 & 0.99 \\
\hline & Rotterdam & & & & & & & & & & & 0.33 & 0.99 \\
\hline \multirow[t]{2}{*}{4} & Antwerp & $\cdot$ & $\cdot$ & $\cdot$ & & & & & & & & 1 & 0.91 \\
\hline & Rotterdam & & & & & & & & & & & 0.56 & 0.94 \\
\hline \multirow[t]{2}{*}{5} & Antwerp & - & - & . & . & & & & & & & 1 & 0.91 \\
\hline & Rotterdam & & & & & & & & & & & 0.55 & 0.94 \\
\hline \multirow[t]{2}{*}{6} & Antwerp & • & - & . & . & · & & & & & & 0.30 & 0.88 \\
\hline & Rotterdam & & & & & & & & & & & 0.66 & 0.94 \\
\hline \multirow[t]{2}{*}{7} & Antwerp & • & $\cdot$ & - & . & $\cdot$ & $\cdot$ & & & & & 0.30 & 0.89 \\
\hline & Rotterdam & & & & & & & & & & & 0.65 & 0.95 \\
\hline \multirow[t]{2}{*}{8} & Antwerp & $\cdot$ & $\cdot$ & • & $\cdot$ & $\cdot$ & $\cdot$ & $\cdot$ & & & & 0.51 & 0.92 \\
\hline & Rotterdam & & & & & & & & & & & 0.56 & 0.95 \\
\hline \multirow[t]{2}{*}{9} & Antwerp & • & - & . & . & $\cdot$ & • & • & . & & & 0.57 & 0.88 \\
\hline & Rotterdam & & & & & & & & & & & 0.59 & 0.94 \\
\hline \multirow[t]{2}{*}{10} & Antwerp & - & . & - & $\cdot$ & • & $\cdot$ & $\cdot$ & · & - & & 0.26 & 0.78 \\
\hline & Rotterdam & & & & & & & & & & & 0.62 & 0.94 \\
\hline
\end{tabular}




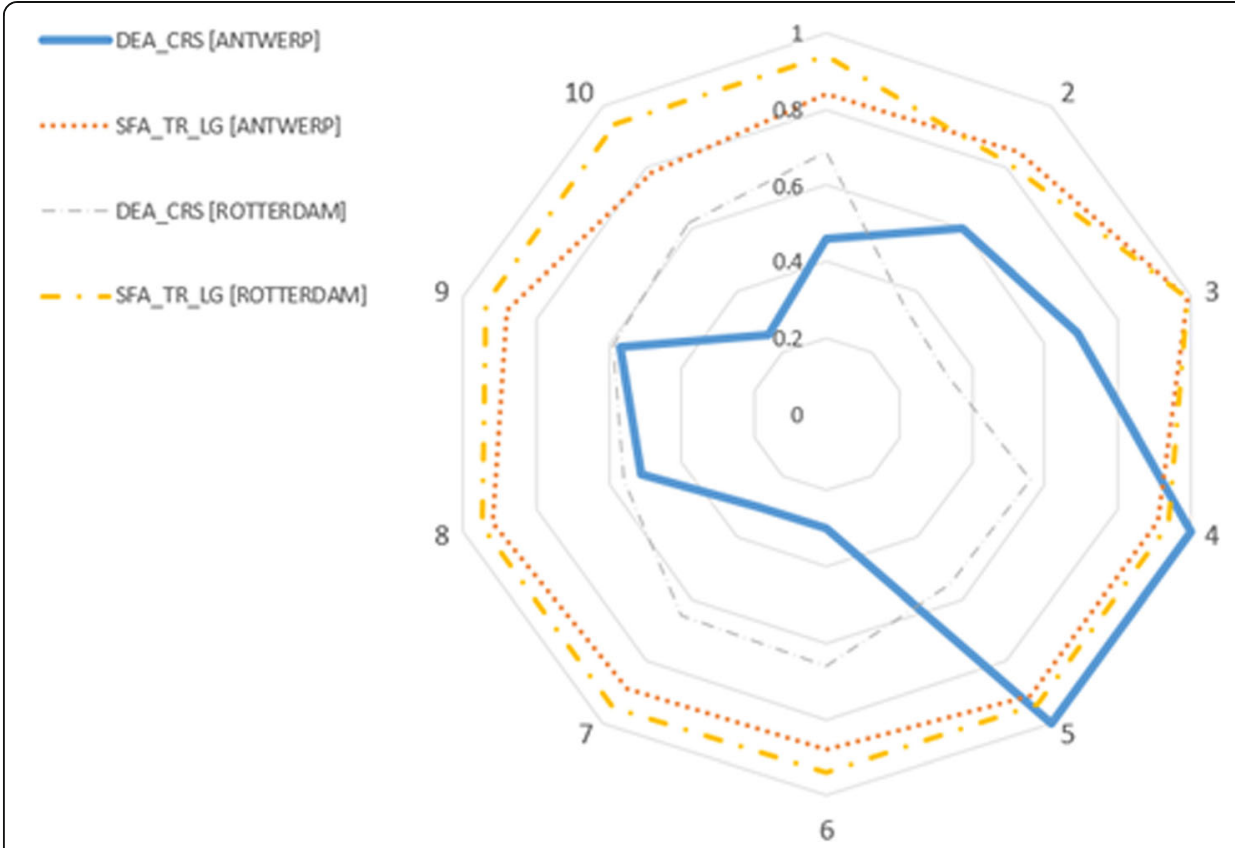

Fig. 2 Relationship between the parametric and non parametric efficiency scores

techniques to verify the potential impact of specific measures. In particular, the result for the labour indicator provides evidence for the relevance of the assumptions connected to it, showing significant differences among the performance evaluation. Accordingly, since the number of workers can be used to verify the efficacy of employment policies, especially when the implementation of new policies concerns definite (NACE) labour categories, management can design policy actions throughout the model proposed in the current work. Furthermore, the involvement of the NUTS2 territorial districts should be relevant to define policy measures according to the peculiarities (heterogeneity) of a specific region, as well as the impact of the national law on the reorganisation process of each port. In fact, the role of the government has strategic importance in regard to interventions aimed at a specific business, and could incorporate components connected to ports handling multiple NUTS2 regions. Even though current empirical work analyses a limited set of indicators, the outcomes highlighted the importance of their selection, and confirm the critical role of the DEA and SFA approaches as tools to support management decisions since they allow to verify the consistency of the different efficiency estimations.

One of the main limits of the current research concerns the output, since port activity is no longer limited to just cargo handling. Further investigation on the involvement of additional criteria that can be considered when the NACE/NUTS levels appear to be not fully satisfactory. For instance, features connected to ports which are close to regional border handling multiple NUTS2 districts should be debated. Several contextual factors must also be considered in the benchmark analysis to detect whether they affect port efficiency. 


\section{Abbreviations}

CRS or CCR: Constant returns to scale; CTL: Terminal quay length; DEA: Data envelopment analysis; DMU: Decisions making unit; GDP: Gross domestic product; NACE: European statistical classification of economic activ; NIRS: Nonincreasing returns to scale; NOE: Number of employees; NUTS: Nomenclature of territorial units for statistics; SFA: Stochastic frontier analysis; TE: Technical efficiency; TGW: Total gross weight of goods handled in each port; VRS or BCC: Variable returns to scale

\section{Acknowledgements}

The authors are grateful to Professor Manolis Kavussanos and two anonymous referees for their helpful reviews and suggestions at the IAME 2019 conference where an earlier version of this paper was presented. We are also grateful to Professor Kee-Hung Lai and two different anonymous referees for their comments during the submission procedure of this article to Journal of Shipping and Trade.

\section{Authors' contributions}

All authors have directly contributed to the planning, analysis, and writing of the paper. The authors have read and approved the final manuscript.

\section{Authors' information}

Claudio Quintano is Emeritus Professor of Economic Statistics. E-mail: claudio.quintano@uniparthenope.it Paolo Mazzocchi is Associate Professor of Economic Statistics. E-mail: paolo.mazzocchi@uniparthenope.it Antonella Rocca is an Assistant Professor of Economic Statistics. E-mail: antonella.rocca@uniparthenope.it

\section{Funding}

This research did not receive any specific grant from funding agencies in the public, commercial, or not-for-profit sectors.

\section{Availability of data and materials}

All data generated or analysed during this study are included in this published article.

\section{Competing interests}

The authors declare that they have no competing interests.

Received: 29 July 2019 Accepted: 21 September 2020

Published online: 14 October 2020

\section{References}

Aigner D, Lovell KCA, Schmidt P (1977) Formulation and estimation of stochastic frontier production function models. J Econ 6(1):21-37

Alijohani K, Thompson R (2016) Impacts of logistics sprawl on the urban environment and logistics: taxonomy and review of literature. J Transp Geogr 57:257-263

Almawsheki ES, Shah MZ (2015) Technical efficiency analysis of container terminals in the middle eastern region. Asian J Ship Logist 31(4):477-486

Antão P, Calderón M, Puig M, Wooldridge C, Darbra RM (2016) Identification of occupational health, safety, security (OHSS) and environmental performance indicators in port areas. Saf Sci 85:266-275

Banker RD, Charnes A, Cooper W (1984) Some models for estimating technical and scale inefficiencies in data envelopment analysis. Manag Sci 30(9):1078-1092

Barros CP (2003) The measurement of efficiency of portuquese sea port authorities with DEA. Int J Transp Econ 30(3):335-354

Barros CP (2005) Decomposing growth in Portuguese seaports: a frontier cost approach. Marit Econ Logist 7(4):297-315

Barros CP (2006) A benchmark analysis of italian seaports using DEA. Marit Econ Logist 8(4):347-365

Barros CP (2012) Productivity assessment of African seaports. Afr Dev Rev 24(1):67-78

Barros CP, Haralambides H, Hussain M, Peypoch N (2011) Seaport efficiency and productivity growth. In: Cullinane KPB (ed) International handbook of maritime economics. Edward Elgar, Cheltenham, pp 363-382

Barros CP, Peypoch N (2007) Comparing productivity change in Italian and portuguese seaports using the Luenberger indicator approach. Marit Econ Logist 9(2):138-147

Battese G, Coelli T (1992) Frontier production function, technical efficiency and panel data: with application to paddy farmer in India. J Prod Anal 3:153-169

Battese G, Coelli T (1995) A model for technical in efficiency effects in a stochastic frontier production function for panel data. Empir Econ 20:325-332

Baynes T, Lenzen M, Steinberger JK, Bai X (2011) Comparison of household consumption and regional production approaches to assess urban energy use and implications for policy. Energy Policy 39:7298-7309

Bottasso A, Conti M, Ferrari C, Merk O, Teia A (2013) The impact of port throughput on local employment: evidence from a panel of European regions. Transp Policy 27:32-38

Bruno G, Corsini V, Monducci R (1999) Dynamics of Italian industrial firms; microeconomic analysis of performance and labour demand from 1989 to 1994. In: Biffignandi S (ed) Micro- and macrodata of firms statistical analysis and international comparison - contributions in statistics. Springer Verlag, Boston, pp 543-570

Bulut E, Durur O (2018) Analytic hierarchy process (AHP) in maritime logistics: theory, application and fuzzy set integration. In: Lee PTW, Yang Z (eds) Multi-criteria decision making in maritime studies and logistics - international series in operations research \& management science. Springer Verlag, New York, pp 31-78

Cariou P, Fedi L, Dagnet F (2014) The new governance structure of French seaports: an initial post-evaluation. Marit Policy Manag 41(5):430-443 
Castelein RB, Geerlings H, Van Duin JHR (2019) The ostensible tension between competition and cooperation in ports: a case study on intra-port competition and inter-organizational relations in the Rotterdam container handling sector. J Shipp Trade. https://doi.org/10.1186/s41072-019-0046-5

Censis (2015) The fifth maritime economy report, Roma http://www.federazionedelmare.it/images/pubblicazioni/ vrapportoeconomiamare_2015.pdf Accessed 23 Apr 2018

Chang CC, Wang CM (2012) Evaluating the effects of green port policy: case study of Kaohsiung harbour in Taiwan. Transp Res Part D: Transp Environ 17:185-189

Chang YT, Park HK, Lee S, Kim E (2018) Have emission control areas (ecas) harmed port efficiency in Europe? Transp Res Part D: Transp Environ 58:39-53

Charnes A, Cooper WW, Rhodes E (1978) Measuring the efficiency of decision making units. Eur J Oper Res 2(6):429-444

Cheon S, Dowall D, Song DW (2010) Evaluating impacts of institutional reforms on port efficiency changes: ownership, corporate structure, and total factor productivity changes. Transp Res Part E: Logist Transp 46(4):546-561

Christensen LR, Jorgenson DW, Lau LJ (1973) Transcendental logarithmic production frontiers. Rev Econ Stat 55:28-45

Coelli TJ, Rao DSP, O'donnell CJ, Battese GE (2005) An introduction to efficiency and productivity analysis. Springer Verlag, Boston

Cook WD, Seiford LM (2009) Data envelopment analysis - thirty years on. Eur J Oper Res 192(1):1-17

Cook WD, Zhu J (2005) Modelling performance measurement - application and implementation issues in DEA. Springer Verlag, Boston

Coto-Millan P, Banos-Pino J, Rodriguez-Alvarez A (2000) Economic efficiency in Spanish ports: some empirical evidence. Marit Policy Manag 27(2):169-174

Cullinane KPB, Song DW, Ji P, Wang TF (2004) An application of DEA windows analysis to container port production efficiency. Rev Netw Econ 3(2):184-206

Cullinane KPB, Wang TF, Ji P, Song DW (2006) The technical efficiency of container ports: comparing data envelopment analysis and stochastic frontier analysis. Transp Res Part A: Policy Pract 40(4):354-374

De Langen PW, Haezendonck E (2012) Ports as clusters of economic activity. In: Talley WK (ed). The blackwell companion to maritime economics. Wiley-Blackwell, New York, pp 638-655

De Langen PW, Pallis AA (2006) Analysis of the benefits of intra-port competition. Int J Transp Econ 33(1):69-85

Demirel B, Cullinane KPB, Haralambides H (2012) Container terminal efficiency and private sector participation. In: Talley WK (ed) The Blackwell companion to maritime economics. Wiley-Blackwell, New York, pp 571-598

Deng P, Lu S, Xiao H (2013) Evaluation of the relevance measure between ports and regional economy using structural equation modeling. Transp Policy 27:123-133

Dowd TJ, Leschine TM (1990) Container terminal productivity: a perspective. Marit Policy Manag 17(2):107-112

Ensslin L, Dezem V, Dutra A, Ensslin SR, Somensi K (2018) Seaport-performance tools: an analysis of the international literature. Marit Econ Logist 20(4):587-602

Esser A, Sys C, Vanelslander T, Verhetsel A (2019) The labour market for the port of the future. A case study for the port of Antwerp. Case Studies Transp Policy 8(2):349-360

Estache A, Gonzalez M, Trujillo L (2002) Efficiency gains from port reform and the potential for yardstick competition: lessons from Mexico. World Dev 30(4):545-560

European Commission (2016) Commission staff working document on the implementation of the EU maritime transport strategy 2009-2018 https://ec.europa.eu/transport/sites/transport/files/swd2016_326.pdf Accessed 13 Jul 2018

Eurostat (2009) Study in the field of maritime policy - approach towards an integrated maritime policy database. Volume 1: Main part European Commission. https://webgate.ec.europa.eu/maritimeforum/system/files/eurostat_mp_study_final\%2 Oreport_r1_volume_1_mainpart.pdf. Accessed 23 Aug 2018

Eurostat (2017) Eurostat regional yearbook 2017, Statistical books, Luxembourg. http://ec.europa.eu/eurostat/documents/321 7494/8222062/ks-ha-17-001-en-n.pdf/eaebe7fa-0c80-45af-ab41-0f806c433763. Accessed 24 Nov 2018

Eurostat (2020) Maritime transport of goods - quarterly data - Eurostat Statistics Explained, Luxembourg. https://ec.europa.eu/ eurostat/statistics-explained/index.php/Maritime_transport_of_goods_-_quarterly_data\#tTop_European_ports. Accessed 03 Sep 2020

Farrell MJ (1957) The measurement of productive efficiency. J Royal Stat Soc 120:253-281

Fernández-Macho J, González P, Virto J (2016) An index to assess maritime importance in the european Atlantic economy. Mar Policy 64:72-81

Ferrari C, Percoco M, Tedeschi A (2010) Ports and local development: evidence from Italy. Int J Transp Econ 37(1):9-30

Ferreira DC, Marques RC, Pedro MI (2018) Explanatory variables driving the technical efficiency of European seaports: an order-a approach dealing with imperfect knowledge. Transp Res Part E: Logist Transp 119:41-62

Figueiredo De Oliveira G, Cariou P (2015) The impact of competition on container port (in)efficiency. Transp Res Part A: Policy Pract 78:124-133

Gong X, Wu X, Luo M (2019) Company performance and environmental efficiency: a case study for shipping enterprises. Transp Policy 82(C):96-106

Grobar L (2008) The economic status of areas surrounding major u.s. container ports: evidence and policy issues. Growth Chang 39:497-516

Ha MH, Yang Z, Lam JSL (2019) Port performance in container transport logistics: a multi-stakeholder perspective. Transp Policy 73:25-40

Haezendonck E, Langenus M (2019) Integrated ports clusters and competitive advantage in an extended resource pool for the Antwerp seaport. Marit Policy Manag 46(1):74-91

Heitz A, Dablanca L, Olssonb J, Sanchez-Diaz I, Woxenius J (2018) Spatial patterns of logistics facilities in Gothenburg, Sweden. J Transp Geogr. https://doi.org/10.1016/j.jtrangeo.2018.03.005

IAPH - International Association of Ports and Harbours (2007) Resolution on clean air programs for ports. Second plenary session. 25th World ports conference, Houston

Kumbhakar SC, Lovell CAK (2003) Stochastic frontier analysis. Cambridge University Press, Cambridge

Lacoste R, Douet M (2013) The adaptation of the landlord port model to France's major seaports: a critical analysis of local solutions. Marit Policy Manag 40(1):27-47 
Lam JSL, Notteboom T (2014) The greening of ports: a comparison of port management tools used by leading ports in Asia and Europe. Transplant Rev 34(2):169-189

Lampe HW, Hilgers D (2015) Trajectories of efficiency measurement: a bibliometric analysis of DEA and SFA. Eur J Oper Res 240(1):1-21

Laxe FG, Bermúdez FM, Palmero FM, Novo-Corti I (2016) Sustainability and the Spanish port system - analysis of the relationship between economic and environmental indicators. Mar Pollut Bull 113(1-2):232-239

Leloup P (2019) A historical perspective on crime control and private security: a Belgian case study. Polic Soc 29(5):551-565 Leontief W (1936) Quantitative input and output relations in the economic system of the US. Rev Econ Stat 18:105-125

Liu JS, Lu LYY, Lu WM (2016) Research fronts in data envelopment analysis. Omega 58:33-45

Liu Z (1995) The comparative performance of public and private enterprises. J Transp Econ Policy 29(3):263-274

Madeira AG Jr, Cardoso MM Jr, Belderrain MCN, Correia AR, Chwanz SH (2012) Multicriteria and multivariate analysis for port performance evaluation. Int J Prod Econ 140(1):450-456

Meeusen W, Van Den Broeck J (1977) Efficiency estimation from cobb- Douglas production functions with composed errors, Int Econ Rev 18:435-444

Min H, Park B (2005) Evaluating the inter-temporal efficiency trends of international container terminals using data envelopment analysis. Int J Integr Supply Manag 1(3):258-277

Munim ZH, Schramm HJ (2018) The impacts of port infrastructure and logistics performance on economic growth: the mediating role of seaborne trade. J Shipp Trade. https://doi.org/10.1186/s41072-018-0027-0

Murphy B, Veall MR, Zhang Y (2016) Is there evidence of ICT skill shortages in Canadian Taxfiler data? In: Green WH, Khalaf L, Sickles RC, Veall M, Voia MC (eds). Productivity and efficiency analysis. Springer Verlag, Boston, pp 145-160

Nguyen HO, Nguyen HV, Chang YT, Chin ATH, Tongzon J (2016) Measuring port efficiency using bootstrapped DEA: the case of Vietnamese ports. Marit Policy Manag 43(5):644-659. https://doi.org/10.1080/03088839.2015.1107922

Notteboom T (2010) Dock labour and port-related employment in the European seaport system. European Seaport Organisation, University of Antwerp, Belgium

Notteboom T (2012) Dock labour systems in north-west European seaports: how to meet stringent market requirements? Paper 1116 - Satta G. et al. Presented at the International Forum on Shipping, Ports and Airports (IFSPA), Hong Kong

Notteboom T, Coeck C, Van De Broeck J (2000) Measuring and explaining the relative efficiency of container terminals by means of Bayesian stochastic frontier models. Int J Marit Econ 2(2):83-106

Odeck J, Bråthen S (2012) A meta-analysis of DEA and SFA studies of the technical efficiency of seaports: a comparison of fixed and random-effects regression models. Transp Res Part A: Policy Pract 46(10):12-21

OECD (2016) Cruise shipping and urban development the case of Dublin - case-specific policy analysis. The International Transport Forum, Paris https://www.itf-oecd.org/sites/default/files/cruise-shipping-urban-development-dublin.pdf. Accessed 21 Sep 2018

Orea L, Wall A (2016) Measuring eco-efficiency using the stochastic frontier analysis approach. In: Aparicio J, Lovell CAK, Pastor JT (eds) Advances in efficiency and productivity. Springer Verlag, Boston, pp 275-297

Oum TH, Park JH (2004) Multinational firms location preference for regional distribution centers: focus on the northeast Asian region. Transp Res Part E: Logist Transp Rev 40:101-121

Panayides PM, Lambertides N, Savva CS (2011) The relative efficiency of shipping companies. Transp Res Part E: Logist Transp Rev 47(5):681-694

Rios LR, Maçada ACC (2006) Analyzing the relative efficiency of container terminals of Mercosur using DEA. Marit Econ Logist 8(4):331-346

Rivera L, Sheffi Y, Welsch R (2014) Logistics agglomeration in the US. Transp Res Part A: Policy Pract 59:222-238

Roll Y, Hayuth Y (1993) Port performance comparison applying data envelopment analysis. Marit Policy Manag 20(2):153-161

Roos EC, Kliemann-Neto FJ (2017) Tools for evaluating environmental performance at brazilian public ports: analysis and proposal. Mar Pollut Bull 115(1-2):211-216

Sahoo BK, Khoveyni M, Esalmi R, Chaudhury P (2016) Returns to scale and most productive scale size in DEA with negative data. Eur J of Oper Res 255(2):545-558

Shobayo P, Van Hassel E (2019) Container barge congestion and handling in large seaports: a theoretical agent-based modeling approach. J Shipp Trade. https://doi.org/10.1186/s41072-019-0044-7

Suárez-Alemán A, Morales Sarriera J, Serebrisky T, Trujillo L (2016) When it comes to container port efficiency, are all developing regions equal? Transp Res Part A: Policy Pract 86:56-77

Surís-Regueiro JC, Garza-Gil MD, Varela-Lafuente MM (2013) Marine economy: a proposal for its definition in the European Union. Mar Policy 42(c):111-124

Tongzon J (2001) Efficiency measurement of selected Australian and other international ports using data envelopment analysis. Transp Res Part A: Policy Pract 35(2):113-128

Turnbull P (2012) Port labor. In: Talley WK (ed) The Blackwell companion to maritime economics. Wiley-Blackwell, New York, pp 517-548

Turnbull P, Wass V (2007) Defending dock workers—globalization and labour relations in the World's ports. J Econ Soc 46(3): 582-612. https://doi.org/10.1111/j.1468-232X.2007.00481.x

Van Den Bos G, Wiegmans B (2018) Short sea shipping: a statistical analysis of influencing factors on sss in European countries. J Shipp Trade. https://doi.org/10.1186/s41072-018-0032-3

Van Der Lugt LM, De Langen PW (2005) The changing role of ports as locations for logistics activities. J Int Logist Trade 3(2):59-72

Wergeland T (2016) Ferry passenger markets. In: Talley WK (ed) The Blackwell companion to maritime economics. WileyBlackwell, Malden, pp 161-183

Wiegmans B, Witte P (2017) Efficiency of inland waterway container terminals: stochastic frontier and data envelopment analysis to analyse the capacity design- and throughput efficiency. Transp Res Part A: Policy Pract 106:12-21

Zhou P, Poh KL, Ang BW (2007) A non-radial DEA approach to measuring environmental performance. Eur J of Oper Res 178:1-9

\section{Publisher's Note}

Springer Nature remains neutral with regard to jurisdictional claims in published maps and institutional affiliations. 